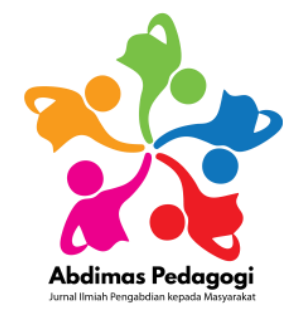

Abdimas Pedagogi: Jurnal Ilmiah Pengabdian kepada Masyarakat

Vol 3, No. 1, 2020, hlm.40—47

\title{
PELATIHAN PERILAKU RESPEK, EMPATI DAN ASERTIF MELALUI METODE ROLE PLAY UNTUK MENCEGAH BULLYING DI SEKOLAH MENENGAH PERTAMA
}

\author{
Ella Faridati Zen, Muslihati, Diniy Hidayaturrahman, Widya Multisari* \\ Jurusan Bimbingan dan Konseling, Fakultas Ilmu Pendidikan, Universitas Negeri Malang, Indonesia \\ Jalan Semarang No. 5 Malang, Jawa Timur, Indonesia \\ *e-mail: widya.multisari.fip@um.ac.id
}

artikel masuk: 28 Januari 2020; artikel diterima:30 April 2020

\begin{abstract}
This activity aims to test the effectiveness of respect, empathy and assertive behavioral training through the role play method as an effort to prevent bullying in Al Furqon Jombang Middle School. The dedication method used is the role playing technique that is tested for success with one group pretest-posttest design. The target of devotion is 28 students of class VII Al Furqon Jombang Middle School. The result is a change in respect for behavior based on an increase in the value of the post test from the pre test value after being treated with training with role playing techniques. Empathy and assertive behavior do not change significantly after training. So there is a need for follow-up through improvements to the development of guidelines.
\end{abstract}

Keywords: Respect; empathy; assertiveness; role playing; bullying

\begin{abstract}
Abstrak: Kegiatan ini bertujuan untuk menguji efektivitas pelatihan perilaku respek, empati dan asertif melalui metode role play sebagai upaya pencegahan bullying di SMP Al Furqon Jombang. Metode pengabdian yang digunakan adalah teknik role playing yang diuji keberhasilannya dengan one group pretest-posttest design. Sasaran pengabdian yakni 28 siswa kelas VII SMP Al Furqon Jombang. Hasilnya terdapat perubahan pada perilaku respek berdasarkan peningkatan nilai pos tes dari nilai pre tes setelah diberikan perlakuan dengan pelatihan dengan teknik role playing. Perilaku empati dan asertif tidak mengalami perubahan nilai yang signifikan setelah pelatihan. Sehingga perlu adanya tindaklanjut melalui perbaikan pada pengembangan panduan.
\end{abstract}

Kata kunci: Respek; empati; asertif; role playing; bullying

\section{PENDAHULUAN}

Siswa SMP merupakan individu dengan tahap perkembangan masa remaja awal. Masa remaja merupakan peralihan dari masa kanak-kanak ke masa dewasa. Sejumlah penyesuaian diharap dapat dilakukan oleh remaja, termasuk penyesuaian dalam kehidupan sosialnya. Remaja yang mampu dalam mengadakan penyesuaian diri maka mereka akan mendapat kehidupan yang 
harmonis dengan diri maupun lingkungannya. juga akan mampu dalam menghadapi masalahmasalah pribadi, sosial, belajar maupun karir.

Fenomena menunjukkan bahwa lingkungan begitu besar pengaruhnya terhadap penyesuaian diri remaja. Kondisi lingkungan yang kurang sehat, seperti penyalahgunaan obat-obat terlarang, maraknya tayangan pornografi dan pornoaksi, ketidakharmonisan kehidupan keluarga, dan dekadensi moral orang dewasa, sangat berpengaruh pada pola perilaku remaja. Dampaknya pada perilaku remaja yang notabene berada pada jenjang pendidikan SMP ataupun SMA dan sederajat, dapat berupa perilaku bermasalah seperti pelanggaran tata tertib sekolah, tawuran antar peserta didik, hingga ke tindakan kekerasan (bullying).

Perilaku bulliying merupakan perilaku yang dilakukan berulang-ulang sekelompok siswa yang memiliki kekuasaan terhadap siswa yang lemah dengan tujuan menyebabkan ketidaksenangan atau menyakitkan oleh orang lain, baik satu atau beberapa orang secara langsung terhadap seseorang yang tidak mampu melawannya (Amalia, 2013; Olweus, 2006). Wiyani (2012) mengemukakan tipologi perilaku bulliying yakni kekerasan terbuka seperti tawuran atau perkelahian, kekerasan tertutup seperti ancaman, kekerasan agresif dan kekerasan defentif. Coloroso (2007) mengemukakan bahwa anak yang menjadi korban bulliying biasanya memiliki karakter anak baru, anak termuda di sekolah, anak yang pernah mengalami trauma, anak penurut, anak yang perilakunya dianggap mengganggu orang lain, anak yang tidak mau berkelahi, anak yang pemalu, anak yang miskin atau kaya, anak yang ras suku etnisnya dipandang inferior oleh penindas, anak yang agamanya dipandang inferior oleh penindas, anak yang memiliki ciri fisik yang berbeda dengan orang lain, anak dengan ketidak cakapan mental atau fisik, dan anak yang berbeda di tempat yang keliru pada saat yang salah.

Data menunjukkan kasus bullying masih marak terjadi berdasarkan berbagai laporan lembaga. Berdasarkan data UNICEF tahun 2016, sebanyak 41 hingga 50 persen remaja di Indonesia pernah mengalami cyber bullying (kumparan.com, 2017). Tahun 2018 KPAI mencatat terdapat 161 kasus kekerasan pada anak (inews.id, 2018). Selanjutnya KPAI juga menyatakan bahwa Januari 2019April 2019 telah terdpaat laporan kasus anak korban kebijakan sebanyak 8 orang, pengeroyokan sebanyak 3 kasus, korban kekerasan seksual sebanyak 3 kasus, kekerasan fisik sebanyak 8 kasus, kekerasan psikis dan bullying sebanyak 12 kasus dan anak pelaku bullying terhadap guru sebanyak 4 kasus (news.detik.com, 2019).

Banyak faktor yang berpengaruh atas munculnya tindakan bully. Tumon (2014) menjabarkan bahwa terdapat sejumlah fator yang membentuk perilaku bullying yakni faktor keluarga, teman sebaya dan sekolah. Selain faktor lingkungan sebagaimana di gambarkan di atas, maka faktor dari dalam dari individu memberikan kontribusi pada tindakan bullying seperti kepercayaan diri (Hervita, 2005), jenis kelamin (Usman, 2013), tipe kepribadian (Utomo, 2013). Salah satu faktor yang penting pada pembentukan perilaku bullying yakni dukungan social (Usman, 2013; Putri, dkk, 2015). Siswa yang memiliki kecenderungan ditolak oleh temannya akan menunjukkan perilaku senang mendebat, mengganggu teman, tidak memiliki rasa malu, dan cenderung agresif.

Fenomena perilaku perundungan potensial juga terjadi di lingkungan SMP Al Furqon Jombang. Hal ini mengingat para siswa SMP yang sedang berada pada masa remaja awal, kondisi emosinya masih labil sehingga kadang menunjukkan sikap yang emosional. Di samping itu, mereka juga suka mencoba-coba (termasuk mencoba perilaku yang melanggar aturan atau norma) dalam proses perolehan identitas dirinya. Kondisi tersebut di antaranya yang menyebabkan munculnya tindakan perundungan.

Perilaku perundungan dapat dikendalikan jika individu memiliki keterampilan dalam berinteraksi sosial secara efektif. Keterampilan tersebut di antaranya yaitu sikap dan tindakan 
respek atau peduli kepada lingkungan atau orang lain, empati yaitu ikut merasakan perasaan orang lain sehingga ia dapat memahami kondisi orang lain, serta sikap asertif, yaitu dapat mengkomunikasikan secara tegas dan tepat apa yang dipikirkan, dirasakan ataupun yang dibutuhkan/ diharapkan tanpa menyinggung perasaan orang lain. Apabila ketiga keterampilan dalam berinteraksi sosial tersebut, yaitu respek, empati dan asertif dimuliki oleh remaja ataupun siswa, maka kemungkinan besar dalam kehidupan sosial atau pergaulan mereka akan terwujud dalam suasana yang harmonis, sehingga jauh dari kesalahpahaman yang merupakan pemantik adanya konflik hingga tindakan perundungan.

Salah satu teknik yang dapat digunakan untuk melatih keterampilan dalam berinteraksi sosial adalah role-play atau bermain peran. Role-play merupakan teknik dalam pembelajaran yang dapat juga diterapkan dalam konteks pelayanan bimbingan, dengan cara memerankan situasi-situasi yang paralel (sama) dengan kehidupan nyata atau yang sebenarnya, digunakan untuk mengembangkan keterampilan hubungan antar manusia. Melalui permainan peranan, anggota kelompok atau siswa belajar melalui model yang ditunjukkan oleh para pemain. Para siswa juga mengembangkan pemahaman dan keterampilan dalam berinteraksi sosial.

\section{METODE}

Metode yang digunakan untuk menyelesaikan masalah yang terjadi pada di SMP Al- Frqon Jombang adalah metode pelatihan perilaku respek, empati dan asertif dengan teknik role playing. Sasaran pelatihan merupakan siswa kelas VIII SMP Al Furqon Jombang Tahun Ajaran 2019/2020 dengan jumlah 28 siswa. Pemilihan sasaran pengabdian menggunakan teknik acak atau random sampling dan terpilih sampel dengan variasi kategori tingkat perilaku respek, empati dan asertif tinggi, sedang, dan rendah.

Pengujian keberhasilan pelatihan dilakukan dengan menggunakan uji eksperimen dengan menggunakan desain one group pretest and posttest design. Pengujian dilakukan dengan membandingkan hasil pretest dan hasil posttest menggunakan angket tingkat perilaku respek, empati dan asertif. Hasil perbandingan pretest dan hasil posttest dilakukan dengan uji beda rerata.

\section{HASIL DAN PEMBAHASAN}

Efektivitas pelatihan perilaku respek, empati dan asertif melalui metode role play sebagai upaya pencegahan bullying di SMP Al Furqon Jombang ditafsirkan berdasarkan hasil pengujian hipotesis yag dijabarkan sebagai berikut.

H0 : rata-rata nilai pretes perilaku respek, empati dan asertif sama dengan nilai rata-rata pos tes perilaku respek, empati dan asertif .

Ha : rata-rata nilai pos tes perilaku respek, empati dan asertif lebih besar dari nilai rata-rata pre tes perilaku respek, empati dan asertif.

\section{Aspek Respek}

Berdasarkan hasil analisis uji beda rerata meunjukkan hasil Nilai t hitung -4.829 sedangkan nilai $t$ tabel 1.703. dengan demikian nilai $t$ hitung lebih besar dari nilai $t$ tabel. Maka hipotesis nul diterima dengan kesimpulan ada perbedaan skor pretes dan postes respek yang diukur sebelum dan setelah perlakuan.

Ada tiga komponen yang membentuk respek (Suyasa, 2010), yaitu: (a) kemampuan menghargai diri pribadi, (b) keseimbangan antara rasio dan emosi; dan (c) sensitifitas terhadap kebutuhan orang lain, dan hak orang lain. respek tidak hanya memahami kebutuhan orang lain tetapi juga diri nya sendiri. Ketika seorang mampu memahami dirinya maka ia akan lebih mudah dalam memahami orang lain. Respek juga terwujud atas adanya keseimbangan emosi yang 
meliputi diri seseorang atau rasa hormat akan mendorong setiap orang untuk mengakui bahwa setiap orang lain layak dihargai sehingga mendorong setiap orang bersikap lembut dan tidak menyakiti orang lain.

Tabel 1. Hasil Analisis Uji Beda Rerata pada Aspek Respek

\begin{tabular}{|c|c|c|c|c|c|c|c|c|c|}
\hline \multicolumn{10}{|c|}{ Paired Samples Test } \\
\hline \multicolumn{10}{|c|}{ Paired Differences } \\
\hline & & \multirow[b]{2}{*}{ Mean } & \multirow{2}{*}{$\begin{array}{c}\text { Std. } \\
\text { Deviatio } \\
\mathrm{n}\end{array}$} & \multirow{2}{*}{$\begin{array}{l}\text { Std. } \\
\text { Error } \\
\text { Mean }\end{array}$} & \multicolumn{2}{|c|}{$\begin{array}{l}95 \% \text { Confidence } \\
\text { Interval of the } \\
\text { Difference }\end{array}$} & \multirow[b]{2}{*}{$\mathrm{t}$} & \multirow[b]{2}{*}{$\mathrm{df}$} & \multirow{2}{*}{$\begin{array}{l}\text { Sig. (2- } \\
\text { tailed) }\end{array}$} \\
\hline & & & & & Lower & Upper & & & \\
\hline Pair 1 & $\begin{array}{l}\text { PRETES_- } \\
\text { RESPEK - } \\
\text { POSTES_- } \\
\text { RESPEK }\end{array}$ & $\begin{array}{r}2.821 \\
43\end{array}$ & 3.09185 & .58430 & -4.02032 & -1.62254 & $\begin{array}{r}- \\
4.82 \\
9\end{array}$ & 27 & .000 \\
\hline
\end{tabular}

Kajian tentang respek salah satunya yakni untuk mencegah bulliying salah dengan pelatihan respek (Hajaroh, M., dkk. 2011, Aryuni, 2017). Secara jelas Frey et al. (2005) menyatakan bahwa bullying dapat dicegah dengan meningkatkan respek yang dimiliki seluruh pihak yang ada disekolah. Program yang dikembangakan oleh Frey et.al (2005) Steps to Respect Program dengan isi program sebagai berikut: (a) peningkatan kesadaran dan reaksi staf pengajar/pendidik terhadap perilaku bullying, (b) penumbuhan tanggung jawab sosialdi antara pendidik, dan (c) peningkatan keterampilan membina hubungan yang sehat secara sosial-emosional bagi siswa, dalam menghadapi bullying.

Melalui pelatihan sosiodrama yang telah dilaksanakan diketahui bahwa terjadi perubahan skor rata-rata pretes dan posttest yang menunjukkan adanya perubahan respek yang terjadi pada peserta. Secara lebih jelas perubahan nilai terjadi dengan adanya peningkatan skor yang dicapai.

\section{Aspek Empati}

Tabel 2. Hasil Analisis Uji Beda Rerata pada Aspek Empati

\begin{tabular}{|c|c|c|c|c|c|c|c|c|c|}
\hline \multicolumn{10}{|c|}{ Paired Samples Test } \\
\hline & \multicolumn{9}{|c|}{ Paired Differences } \\
\hline & & \multirow{2}{*}{$\begin{array}{c}\text { Mea } \\
\mathrm{n}\end{array}$} & \multirow{2}{*}{$\begin{array}{c}\text { Std. } \\
\text { Deviatio } \\
\mathrm{n}\end{array}$} & \multirow{2}{*}{$\begin{array}{l}\text { Std. } \\
\text { Error } \\
\text { Mean }\end{array}$} & \multicolumn{2}{|c|}{$\begin{array}{l}\text { 95\% Confidence } \\
\text { Interval of the } \\
\text { Difference }\end{array}$} & \multirow[b]{2}{*}{$\mathrm{t}$} & \multirow[b]{2}{*}{$\mathrm{df}$} & \multirow{2}{*}{$\begin{array}{l}\text { Sig. } \\
(2- \\
\text { tail } \\
\text { ed) }\end{array}$} \\
\hline & & & & & Lower & Upper & & & \\
\hline Pair 1 & $\begin{array}{l}\text { PRETES_EMPATI - } \\
\text { POSTES_EMPATI }\end{array}$ & $\begin{array}{r}.321 \\
43\end{array}$ & 1.41562 & .26753 & -.22749 & .87035 & $\begin{array}{r}1.20 \\
1\end{array}$ & 27 & $\begin{array}{r}.24 \\
0\end{array}$ \\
\hline
\end{tabular}

Berdasarkan hasil anlaisis uji beda rereta pada aspek empati didapatkan nilai t hitung adalah 1.201 sedangkan $\mathrm{t}$ tabelnya yakni 1.703 dengan demikian $\mathrm{t}$ hitung lebih besar dari hasil $\mathrm{t}$ tabel. Maka hipotesis nul ditolak dengan kesimpulan bahwa tidak ada perbedaaan skor pretes dan posttes aspek empati yang diukur sebelum dan setelah perlakuan.

Sears, dkk (1991) bahwa empati diidentifikasikan sebagai perasaan simpati dan perhatian terhadap orang lain secara spesifik terwujud dalam adanya proses berbagi pengalaman baik secara langsung maupun tidak lain atas perasaan dan kondisi yang dialami oleh orang lain. Sedangkan Leiden, dkk (Asih, 2010) menjabarkan bahwa empati merupakan kemampuan untuk menempatkan 
diri pada posisi orang lain yang seakan-akan menjadi bagian dari dalam dirinya. Individu menginternalisasi rasa yang dialami oleh orang lain kedalam dirinya.

Empati merupakan satu sikap yang dikembangkan untuk dapat mencegah bullying. Melalui perhatian dan kemampuan merasakan apa yang dirasakan oleh orang lain, empati dapat mengendalikan upaya untuk melakukan bullying. Empati memiliki korelasi negatif dengan bullying yang artinya semakin tinggi empati maka semakin rendah (bullying) (Andayani, 2012, Arofa, dkk, 2018).

Sebagaimana upaya yang telah dilakukan oleh pelaksana abdimas dengan mengembangkan sosiodrama untuk meningkatkan empati, terdapat beberapa penelitian yang telah dilakukan. Penelitian yang terlah dilakukan dapat meningkatkan empati melalui teknik sosiodrama (Nur'aini, 2014; Fatmawati, 2014; Andini, 2018). Secara spesifik pengembangan empati melalui teknik sosiodrama dapat mencegah terjadinya tindakan bullying (Fatimatuzzahro, \& Suseno, 2017). Secara kajian empati mestinya dapat dikembangkan melalui teknik sosiodrama dalam mencegah bullying. Tetapi ada beberapa yang mungkin terjadi sehingga secara skor tidak mengalami peningkatan.

\section{Aspek Asertif}

Tabel 3. Hasil Analisis Uji Beda Rerata pada Aspek Empati

\begin{tabular}{|c|c|c|c|c|c|c|c|c|c|}
\hline \multicolumn{10}{|c|}{ Paired Samples Test } \\
\hline \multicolumn{10}{|c|}{ Paired Differences } \\
\hline & & \multirow{2}{*}{$\begin{array}{c}\text { Mea } \\
\mathrm{n}\end{array}$} & \multirow{2}{*}{$\begin{array}{c}\text { Std. } \\
\text { Deviatio } \\
n\end{array}$} & \multirow{2}{*}{$\begin{array}{l}\text { Std. } \\
\text { Error } \\
\text { Mean } \\
\end{array}$} & \multicolumn{2}{|c|}{$\begin{array}{l}\text { 95\% Confidence } \\
\text { Interval of the } \\
\text { Difference }\end{array}$} & \multirow[b]{2}{*}{$\mathrm{t}$} & \multirow[b]{2}{*}{$\mathrm{df}$} & \multirow{2}{*}{$\begin{array}{l}\text { Sig. } \\
(2- \\
\text { tailed })\end{array}$} \\
\hline & & & & & Lower & Upper & & & \\
\hline Pair 1 & $\begin{array}{l}\text { PRETES_A } \\
\text { SERTIF - } \\
\text { POSTES_A } \\
\text { SERTIF }\end{array}$ & $\begin{array}{r}.178 \\
57\end{array}$ & 2.93199 & .55409 & -.95834 & 1.31548 & .322 & 27 & .750 \\
\hline
\end{tabular}

Berdasarkan analisis uji beda rerata pada aspek asertif bahwa nilai t hitungnya 0.322 , sedangkan $\mathrm{t}$ tabelnya 1.703 dengan demikian nilai $\mathrm{t}$ hitungnya lebih kecil dari nilai t tabelnya. Sehingga hipotesis nul diterima dengan kesimpulan bahwa tidak ada perbedaan skor pretest dan posttes pada aspek asertif yang diukur sebelum dan sesudah perlakuan.

Siyanto (dkk, 2014) mengemukakan bahwa asertif merupakan kemampuan mengungkapkan hak dan kebutuhan secara positif tanpa melanggar hak orang lain. Asertif merupakan kondisi yang cukup sulit dilakukan bagi orang yang memiliki kategori submasif atau pasif. Banyak orang tidak berani bersikap asertif karena takut akan tidak disukai atau menyakiti perasaan orang lain. Tetapi kondisi ini justru akan memberikan dampak situasi tidak nyaman dengan bertindak tidak asertif, kita justru bisa membahayakan hubungan jangka panjang kita dengan orang lain.

Asertif merupakan kemampuan seseorang yang dapat dikembangkan untuk mencegah bulliying. Hasil analisis uji beda menunjukkan bahwa latihan asertif dapat membantu untuk mencegah, dan mengurangi perilaku bullying (Keliat, 2012; Herman, 2017; Aini, 2019). Melalui pelatihan asertif peserta diajak untuk mampu menyampaikan pendapat, perasaan dan membela dirinya pada situasi yang tidak nyaman, mengancam, atau membahayakan dirinya. Secara spesifik bahwa teknik sosiodrama telah digunakan untuk mengembangkan kemampuan asertif dalam mencegah bullying (Fidyah, 2018, Rejeki, 2019). Sehingga secara kajian hasil penelitian, sosiodrama dapat digunakan dalam mengembangkan kemampuan asertif dalam mencegah bullying sebagaimana yang dilaksanakan oleh pelaksanan abdimas. 


\section{Analisis Keseluruhan Hasil Uji Beda}

Berdasarkan hasil uji beda rerata tidak aspek yakni respek, empati dan asertif dapat ditarik kesimpulan bahwa hanya aspek respek yang mengalami perubahan skor secara signifikan yang diukur sebelum dan setelah perlakuan. Secara spesifik terjadi peningkatan skor pada aspek respek setelah pemberian treatmen melalui roleplaying. Perubahan skor ini dimungkinkan terjadi karena materi yang diberikan seharusnya dalam satu sesi pelatihan sosiodrama digunakan untuk meningkatkan 3 aspek. Sehingga kurang fokus pada aspek-aspek yang harus ditingkatkan. Pertemuan juga menggunakan sistem blocktime sehingga dimungkinkan berpengaruh terhadap pencapaian hasil belajar. Selain itu evaluasi dilakukan sesaat setelah pelatihan sehingga tidak ada waktu untuk pengendaman transfer of training dari pengalaman belajar yang diperoleh. Transfer of training merupakan penggunaan pengetahuan, keterampilan, dan perilaku yang dipelajari di pelatihan dalam pekerjaan (Kaswin, 2012). Dalam situasi pelatihan yang dilakukan diharapkan siswa peserta pelatihan dalam menerapkan ilmu yang dipelajari melalui sosiodrama dalam kehidupan sehari-hari.

Berdasarkan rancangan pemberian perlakuan mestinya siswa melaksanakan treatmen sebanyak 3 kali dari masing-masing aspek. Karena keterbatsan waktu maka pelaksanaan perlakuan hanya dilaksanakan sejumlah 1 kali pertemuan yang merangkum tiga aspek sekaligus. Dua hari sisanya atau keberlanjutan dari pelaksanaan treatmen dilakukan oleh fasilitator dari sekolah yakni guru BK dan wali kelas untuk melaksanakan role playing ini dengan instruksi dan langkah yang telah diikuti pada pelaksanaan pengabdian.

\section{SIMPULAN}

Kegiatan pelatihan perilaku respek, empati dan asertif melalui metode role play merupakan upaya untuk mencegah perilaku bullying di SMP Al Furqon Jombang. Melalui kegiatan preventif secara terarah, perilaku bulliying dapat diantisipasi dengan lebih bijak. Hasil pelaksanaan pengabdian menunjukkan masih ada satu aspek yakni aspek respek yang berhasil ditingkatkan dengan teknik role playing, dua aspek lainnya perlu diupayakan untuk terus ditingkatkan dengan pemberian pelatihan secara reguler oleh guru BK atau guru pendamping kelasnya.

\section{DAFTAR RUJUKAN}

Aini, K. (2019). Upaya Pencegahan Bullying melalui Pelatihan Komunikasi Asertif. Jurnal Implementasi Pengabdian Kepada Masyarakat, 1 (1).

Amalia. (2013). Perbedaan Perilaku Bulliying ditinjau dari Tipe Pola Asuh Orang Tua pada Siswa-siswi MTsN 2 kediri. Malang: Tesis UIN

Arofa,I., Z., dkk. (2018). Pengaruh Perilaku Bullying terhadap Empati ditinjau dari tipe Sekolah. Jurnal Ilmiah Psikologi Terapan, 6 (1).

Aryuni,M. 2017. Strategi Pencegahan Bulliying melalui Program "Sekolah Care" bagi Fasilitator Sebaya. Asian Journal of Environment, History and Heritage. 1(1): 211-22.

Asih, G.Y. (2010). Perilaku Prososial ditinjau dari Emosi dan Kematangan Emosi. Jurnal Psikologi Universitas Muria Kudus, 1 (1) : 33-42.

Coloroso, B. 2007. Penindas, Tertindas, dan Penonton. Resep Memutus Rantai. Kekerasan Anak dari Prasekolah Hingga SMU. Jakarta : Serambi.

Fatimatuzzahro, A., \& Suseno, M.N. (2017). Efektivitas Terapi Empati untuk Menurunkan Perilaku Bullying pada Anak Usia Sekolah Dasar. Jurnal Empati, 7 (3): 362-378.

Fatmawati, N. ((2014). Peningkatan Sikap Empati mellaui Teknik Sosiodrama pada Siswa Kelas VII SMP Negeri 2 Berbah Selatan Tahun 2013/2014. Yogyakarta: Skripsi UNY. 
Fidyah, F. (2018). Penggunaan Teknik Konseling Kelompok Teknik Sosiodrama untuk Meningkatkan Perilaku Asertif Siswa Kelas X SMA Negeri 11 Bandar Lampung Tahun Pelajaran 2018/2019. Lampung: Universitas Negeri Lampung.

Frey, K. et.al. (2005). Reducing Playground Bullying and Supporting Beliefs: AnExperimental Trial of the Steps to Respect Program. Developmental Psychology, 41,479-491. doi: 10.1037/0012-1649.41.3.479.

Hajaroh, M., dkk. (2011). Pelatihan Respect Education (In-House Training) untuk Mencegah Bullying di Sekolah Dasar Kawasan Beresiko. Yogyakarta: LPPM UNY (PKM).

Herman, H. (2017). Pengaruh Latihan Keteramplan Asertif terhadap Pencegahan Perilaku Bullying. Padang: Universitas Andalas.

Hervita, W. (2005). Pengaruh Pelatihan Pengenalan Kepercayaan Diri Mahasiswa. Yogyakarta: Universitas Islam Indonesia (Skripsi).

Keliat, S.A. (2012). Latihan Asertif dalam Mencegah Bulliying pada Remaja. Jakarta : Universitas Indonesia.

Nur'aini, E.,P. (2014). Pengembangan Sosiodrama denga teknik Gerak dan Lagu dalam Penanaman Rasa Empati. Surabaya: Skripsi UIN Surabaya.

Olweus. (2006). Bullying in Schools: Facts and Intervention. Norwegia: Research Center for Helath Promotion, University of Bergen

Putri, dkk. (2015). Faktor-faktor yang Berhubungan dengan Perilaku Bullying pada Remaja. Jurnal Online Mahasiswa, 2(2).

Rahayu, L.S.(2019). KPAI- Angka Kekerasan pada Anak Januari-April 2019 (online) https://news.detik.com/berita/d-4532984/kpai-angka-kekerasan-pada-anak-januari-april2019-masih-tinggi

Rejeki, H., W. (2019). Membangun Tingkah Laku Asertif mellaui Pengembangan Modul Teknik SOMA untuk Mencegah dan Mengatasi Bullying. Jurnal Education and Development, 7(2).

Sears, dkk. (1991). Psikologi Sosial. Jilid 2. Alih Bahasa: Michael Adryanto. Jakarta: Erlangga.

Siyanto, dkk. (2014). Perilaku Asertif dan kecenderungan Kenakalan Remaja Berdasarkan Pola Asuh dan Peran Media Massa. Jurnal Psikologi, 4l(1).

Suyasa, T. (2010). Identifikasi Fenomena, Faktor, dan Fungsi Respect sebagai Usaha Peningkatan Kualitas (Nilai-nilai \& Sikap Kerja Positif) Sumber Daya Manusia. https://www.researchgate.net/profile/P_Tommy_Y_Suyasa/publication/260750898_Identifi kasi_Fenomena_Faktor_dan_Fungsi_Respect_sebagai_usaha_Peningkatan_Kualitas_Nilaini lai_Sikap_Kerja_Positif_Sumber_Daya_Manusia/links/0deec5321f31611b5a000000.pdf. Diakses pada 6 Desember 2019.

Tumon,B.M. (2014). Studi Deskriptif Perilaku Bullying pada Remaja. Journal Ilmiah Mahasiswa Universitas Surabaya, 3(1).

Usman. I. (2013). Perilaku Bullying ditinjau dari Peran Kelompok Tean Sebaya dan Iklim Sekolah pada Siswa SMA di Kkota Gorontalo. Gorontalo: Universitas Negeri Gorontalo.

Utomo. A.B. (2013). Perbedaan Tipe Kepribadian Ekstrovert dan Introvert dalam Frekuensi Terkena Bullying (Studi Kepada Siswa SMA Negeri 3 Slaatiga). Salatiga: Universitas Satya Wacana

Wiyani (2012). Save Our Children From School Bullying. Yogyakarta: Ar-Ruzz Media .(2017). Kasus Bulliying Meningkat di Dominasi oleh Remaja. (online) https://kumparan.com/@kumparanstyle/kasus-bullying-meningkat-pelaku-didominasi-olehremaja 
.(2018). KPAI Catat 161 Kasus Kekerasan Anak pada bidang Pendidikan. (online) https://www.inews.id/news/nasional/kpai-catat-161-kasus-kekerasan-anak-di-bidangpendidikan-selama-2018/189701 